\title{
Andersen Syndrome
}

National Cancer Institute

\section{Source}

National Cancer Institute. Andersen Syndrome. NCI Thesaurus. Code C84559.

A form of long QT syndrome characterized by ventricular arrhythmia, muscle weakness,

and developmental abnormalities which include micrognathia, low-set ears and

deformities of the fingers. 